\title{
THE INTESTINAL PARASITES OF AN ASSEMBLAGE OF STREAM FISHES IN CENTRAL UTAH
}

\author{
Matthew Rambo ${ }^{1}$, Ashlee N. Smith², Mehmet Cemal Oguz ${ }^{2,3}$, and Mark C. Belk ${ }^{2}$
}

\begin{abstract}
Parasite communities of stream fish assemblages in the western United States are poorly known. We investigated the intestinal parasites of an assemblage of stream fishes in Spanish Fork River in central Utah, USA. Two species, mottled sculpin (Cottus bairdii) and redside shiner (Richardsonius balteatus), had no observable parasites. In the other 3 species, southern leatherside chub (Lepidomeda aliciae), mountain sucker (Catostomus platyrhynchus), and longnose dace (Rhinichthys cataractae), we identified metacercia of an unidentified trematode. We found adult cestodes in southern leatherside chub only. Prevalence and intensity of parasites was highest in southern leatherside chub. Reasons for differential prevalence and intensity of parasites among host fish species are unknown, but there seems to be no relationship to trophic position or habitat use in this fish community.
\end{abstract}

RESUMEn.-Conocemos poco sobre las comunidades de parásitos en los ensambles de peces de río del oeste de Estados Unidos. Estudiamos los parásitos intestinales de un ensamble de peces de río en Spanish Fork River, en el centro de Utah, Estados Unidos. Cottus bairdii y Richardsonius balteatus, no tenían parásitos observables. En las otras tres especies, Lepidomeda aliciae, Catostomus platyrhynchus y Rhinichthys cataractae, identificamos metacercarias relacionadas con un trematodo no identificado. Sólo encontramos céstodos adultos en L. aliciae. La prevalencia y la intensidad de parásitos en L. aliciae fueron mayores en el sur. Desconocemos los motivos de las diferencias en la prevalencia e intensidad de parásitos entre especies de peces portadoras, pero no parece haber ninguna relación con la posición trófica o el uso del hábitat de esta comunidad de peces.

Fish parasites can have potentially significant effects on the health (Hursky and Pietrock 2015), reproductive output (Moravec and Barton 2015), and behavior (Barber et al. 2000) of their hosts. However, understanding large-scale patterns of parasite infection and ecological processes that affect host-specific transmission of parasites within a community requires comparison among geographically and taxonomically diverse populations (Poulin and Forbes 2012, Heins et al. 2014, Strona 2015). Stream fishes of the western USA represent a taxonomically and geographically unique assemblage, and parasites of these fishes are not well known. Recent studies of fish parasites in western North American streams and rivers have focused on metozoan parasites in salmonids. Concern about whirling disease caused by Myxobolus cerebralis has prompted a significant effort directed toward detection and management of this protozoan (Kaeser et al. 2006, Koel et al. 2006, Eby et al. 2015, Fetherman et al. 2015, Murcia et al. 2015, Nehring et al. 2015). Whereas, the effort to curb whirling disease is an important management goal for salmonid sport fishes, the consequence has been that studies on internal nonprotozoan parasites in stream fishes of the western United States have been neglected.

Community structure of parasites can vary depending on the habitat and life histories of host fish species (Weichman and Janovy 2000, Timi and Poulin 2003, Alarcos and Timi 2012, Muñoz 2014). Documenting patterns of parasite prevalence and intensity among stream fish species with different diets, habitats, and life history strategies allows us to infer mechanisms of parasite infection and parasite-host interaction (Fiorillo and Font 1996, Barger and Esch 2001, 2002, Morand et al. 2002, Hernandez et al. 2007, Pérez-del-Olmo et al. 2009). In this paper we document the intestinal parasites of an assemblage of native stream fishes in Spanish Fork River in central Utah. This report provides comparative data on parasites of an underrepresented assemblage of stream fishes.

We surveyed for intestinal parasites in 5 species of co-occurring native stream fishes from the Spanish Fork River in Utah County,

\footnotetext{
IDepartment of Plant and Wildlife Sciences, Brigham Young University, Provo, UT. E-mail: yojinbo86@gmail.com

${ }^{2}$ Department of Biology, Brigham Young University, Provo, UT.

${ }^{3}$ Biology Department, Faculty of Science, Ataturk University, 25240, Erzurum, Turkey.
} 
TABLE 1. Host fish species, parasite taxa, number of parasites, prevalence (number of infected fish divided by total number of fish dissected), and intensity (number of total parasites divided by number of infected fish) in Spanish Fork River, Utah, USA. No parasites were found in mottled sculpin (Cottus bairdii) or redside shiner (Richardsonius balteatus).

\begin{tabular}{|c|c|c|c|c|c|c|}
\hline Fish species & Habitat & Diet & Parasite & $\begin{array}{l}\text { Number of } \\
\text { parasites }\end{array}$ & Prevalence & Intensity \\
\hline \multirow[t]{2}{*}{$\begin{array}{l}\text { Lepidomeda } \\
\text { aliciae }\end{array}$} & Midwater & Carnivorous & $\begin{array}{l}\text { Trematoda } \\
\quad \text { (metacercaria) }\end{array}$ & 611 & $25.0 \%$ & 47 \\
\hline & & & Cestoda & 3 & $5.7 \%$ & 0.2 \\
\hline $\begin{array}{l}\text { Catostomus } \\
\quad \text { platyrhynchus }\end{array}$ & Benthic & Herbivorous & $\begin{array}{l}\text { Trematoda } \\
\text { (metacercaria) }\end{array}$ & 3 & $3.5 \%$ & 3 \\
\hline $\begin{array}{l}\text { Rhinichthys } \\
\text { cataractae }\end{array}$ & Benthic & Omnivorous & $\begin{array}{l}\text { Trematoda } \\
\quad \text { (metacercaria) }\end{array}$ & 3 & $2.5 \%$ & 3 \\
\hline
\end{tabular}

Utah $\left(40^{\circ} 00^{\prime} 52.94^{\prime \prime} \mathrm{N}, 111^{\circ} 29^{\prime} 50.44^{\prime \prime} \mathrm{W}\right)$. Specifically, they are southern leatherside chub (Lepidomeda aliciae), redside shiner (Richardsonius balteatus), and longnose dace (Rhinichthys cataractae)—all 3 in the family Cyprinidae; mottled sculpin (Cottus bairdii: Cottidae); and mountain sucker (Catostomus platyrhynchus: Catostomidae). Southern leatherside chub and redside shiner are found in the midwater column in areas of slow current, and they feed on aquatic macroinvertebrates (Bell and Belk 2004, Nannini and Belk 2006, Wesner and Belk 2015). Longnose dace are benthopelagic omnivorous fishes and mottled sculpin are benthic carnivorous fishes. Both occur in habitats with faster current velocities and feed on aquatic macroinvertebrates (Sigler and Sigler 1987). Mountain sucker are benthic, mostly herbivorous fish that occur in habitats with faster current velocities. (Sigler and Sigler 1987, Wesner and Belk 2015).

We collected and dissected small samples of each species each week from mid-September to late November 2014. In total, we examined 52 southern leatherside chub, 28 mountain suckers, 40 longnose dace, 50 mottled sculpin, and 23 redside shiner. Samples of all species included a mix of juveniles and adults. To examine fish for parasites, we split the intestinal tracts (including stomachs) and carefully examined the inside under a dissecting microscope at $10 \times$ to $20 \times$ magnification. We temporarily preserved all parasites in an alcoholformaldehyde-acetic acid (AFA) solution, then stained them using the following process: $70 \%$ alcohol for $20 \mathrm{~min}, 30 \%$ alcohol for $15 \mathrm{~min}$, water for $15 \mathrm{~min}$, Mayer's stain for 5-10 min, water for $15 \mathrm{~min}, 30 \%$ alcohol for $10 \mathrm{~min}$, $70 \%$ alcohol for $10 \mathrm{~min}, 90 \%$ alcohol for 5 min, 100\% alcohol for $3 \mathrm{~min}$, xylene for $1 \mathrm{~min}$, and Canada balsam for the permanent mount (Pritchard and Kruse 1982). We identified parasite species using the keys and descriptions in Hoffman (1999). We calculated prevalence of parasites as number of infected fish divided by total number of fish dissected, and intensity of parasites as number of total parasites divided by number of infected fish (Bush et al. 1997).

We found 2 species of parasites among all fishes examined (Table 1): a single unidentified trematode species and a single cestode species that is either Biacetabulum sp. or Glaridacris sp. However, identifying these individuals to the species level is challenging because cestodes have many similar morphological features, and genetic tests are necessary to discriminate between species. We found trematode metacercaria (Fig. 1) in southern leatherside chub, mountain suckers, and longnose dace, but no parasites were detected in mottled sculpin and redside shiner. Prevalence and intensity of the trematode metacercaria were considerably higher in southern leatherside chub than in mountain suckers and longnose dace (Table 1). We found adults of a cestode (either Biacetabulum sp. or Glaridacris sp.) in the family Caryophyllaeidae (Fig. 2) only in southern leatherside chub.

Parasites with complex life cycles (like the 2 species we found) use trophic webs as a route of transmission between fish hosts (Timi et al. 2011, Rossiter and Sukhdeo 2014). By exploiting predator interactions in an aquatic system, parasites can evolve transmission tactics and promote host range expansion (Strona 2015). Thus, we expected to find similar parasite occurrence and prevalence in species with similar diets (i.e., southern leatherside chub and redside shiner, or longnose dace and mottled sculpin). On the contrary, almost all parasites were found inside the digestive tracts of southern leatherside chub, and none were found in redside shiner and mottled 


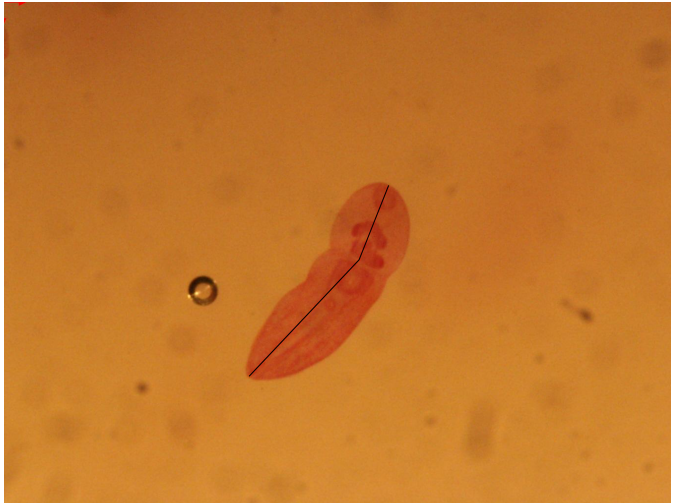

Fig. 1. Trematode metacercaria removed from the intestinal tract of Lepidomeda aliciae. Length is $1.31 \mathrm{~mm}$, indicated by black measurement line.

sculpin. This pattern suggests strong host specificity rather than a general pattern of trophic transmission.

Host specificity is rare in stream fishes (Barger and Esch 2002, Vincent and Font 2003). Thus, another likely explanation for the pattern we observed is high temporal variation in parasite communities and a tendency toward stochastic dynamics (Bartha et al. 1997, Morand et al. 2002, Kennedy 2009). Under this view, parasite occurrence and prevalence are unpredictable, and associations between parasites and hosts result mostly from chance events and conditions rather than as a consequence of ecologically based assembly rules or host specificity. The low level of trematode metacercia found in mountain suckers and longnose dace is consistent with an accidental infection as predicted by stochastic models of community composition and structure (Bartha et al. 1997, Morand et al. 2002, Kennedy 2009). In contrast, the high levels of infestation in leatherside chub are likely a result of host specificity of cestodes (Calentine et al. 1970). There appear to be few general rules that govern parasite occurrence in freshwater fish assemblages (Kennedy 2009, Bellay et al. 2012). One reason may be that the environment in which these fish live is also highly variable both seasonally and within seasons (Braicovich and Timi 2010). Additional studies of parasite communities in stream fishes are required to test these hypotheses. We view this study as a baseline that will provide opportunity for comparison with future efforts.

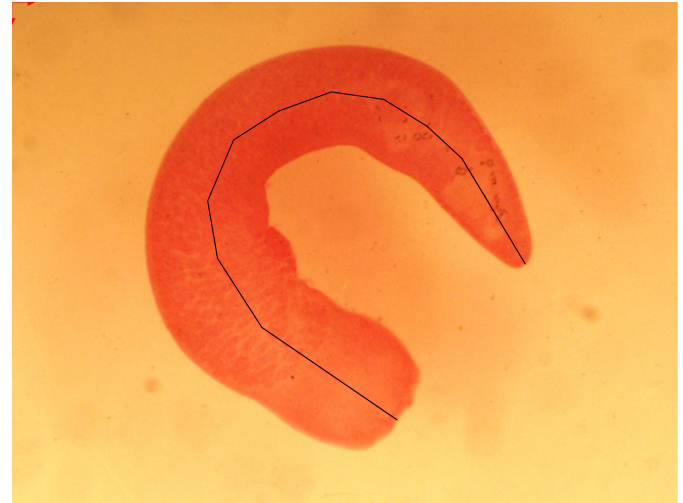

Fig. 2. Adult Biacetabulum sp. or Glaridacris sp. (Cestoda) removed from intestinal tract of Lepidomeda aliciae. Length is $6.50 \mathrm{~mm}$, indicated by black measurement line.

We thank the Biology Department at Brigham Young University, the Utah Department of Wildlife Resources for collection permits, and members of the Fish Parasitology and Ecology class for assisting in dissections. We also thank Dr. Tomas Scholz and Dr. Mikulas Oros for help with parasite determination.

\section{Literature Cited}

Alarcos, A.J., And J.T. Timi. 2012. Parasite communities in three sympatric flounder species (Pleuronectiformes: Paralichthyidae). Parasitology Research 110: 2155-2166.

Barber, I., D. Hoare, and J. Krause. 2000. Effects of parasites on fish behavior: a review and evolutionary perspective. Reviews in Fish Biology and Fisheries 10:131-165.

Barger, M.A., AND G.W. Esch. 2001. Downstream changes in the composition of the parasite community of fishes in an Appalachian stream. Journal of Parasitology 87:250-255.

Barger, M.A., AND G.W. Esch. 2002. Host specificity and distribution-abundance relationship in a community of parasites infecting fishes in streams of North Carolina. Journal of Parasitology 88:446-453.

Bartha, S., T. CZaran, and I. SCheuring. 1997. Spatiotemporal scales of non-equilibrium community dynamics: a methodological challenge. New Zealand Journal of Ecology 21:199-206.

Bell, A., AND M.C. BelK. 2004. Diet of leatherside chub, Snyderichthys copei, in the fall. Western North American Naturalist 64:413-416.

Bellay, S., R.M. Takemoto, and E.F. Oliveira. 2012. Is the community of fish parasites structured in a neotropical floodplain? Acta Parasitologica 57:53-60.

Braicovich, P.E., AND J.T. Timi. 2010. Seasonal stability in parasite assemblages of the Brazilian flathead, Percophis brasiliensis (Perciformes: Percophidae): predictable tools for stock identification. Folia Parasitologica 57:206-212. 
Bush, A.O., K.D. Lafferty, J.M. Lotz, And A.W. Shostak. 1997. Parasitology meets ecology on its own terms: Margolis et al. revisited. Journal of Parasitology 83:575-583.

Calentine, R.L., B.M. Christensen, and L.A. ChrisTENSEN. 1970. Specificity of caryophyllaeid cestodes for their intermediate hosts. Journal of Parasitology 56:346-349.

Eby, L.A., R. Pierce, M. Sparks, K. Carim, and C. Ponder. 2015. Multistage prediction of whirling disease risk in the Blackfoot River Basin, Montana: a useful consideration for restoration prioritization? Transactions of the American Fisheries Society 144:753-766.

Fetherman, E.R., D.L. Winkelman, L.L. Bailey, G.J. SCHISLER, AND K. Davies. 2015. Brown trout shortterm survival and movement of Myxobolus cerebralisresistant rainbow trout. Transactions of the American Fisheries Society 144:610-626.

FioriLLO, R.A., AND W.F. FONT. 1996. Helminth community structure of four species of Lepomis (Osteichthyes: Centrarchidae) from an oligohaline estuary in southeastern Louisiana. Journal of the Helminthological Society of Washington 63:24-30.

Heins, D.C., K.A. Barry, and L.A. Petrauskas. 2014. Consistency of host responses to parasitic infection in three-spined stickleback fish infected by the diphyllobothriidean cestode Schistocephalus solidus. Biological Journal of the Linnean Society 113:958-968.

Hernandez, A.D., J.F. Bunnell, and M.V.K. Sukhdeo. 2007. Composition and diversity patterns in metazoan parasite communities and anthropogenic disturbance in stream ecosystems. Parasitology 134:91-102.

Hoffman, G.L. 1999. Parasites of North American freshwater fishes. 2nd edition. Cornell University Press, Ithaca, NY.

Hursky, O., AND M. Pietrock. 2015. Intestinal nematodes affect selenuim bioaccumulation, oxidative stress biomarkers, and health parameters in juvenile rainbow trout (Oncorhynchus mykiss). Environmental Science and Technology 49:2469-2476.

Kaeser, A.J., C. Rasmussen, and W.E. Sharpe. 2006. An examination of environmental factors associated with Myxobolus cerebralis infection of wild trout in Pennsylvania. Journal of Aquatic Animal Health 18: 90-100.

Kennedy, C.R. 2009. The ecology of parasites of freshwater fishes: the search for patterns. Parasitology 136:1653-1662.

Koel, T.M., D.L. Mahony, K.L. Kinnan, C. Rasmussen, C.J. Hudson, S. Murcia, and B.L. Kerans. 2006. Myxobolus cerebralis in native cutthroat trout of the Yellowstone lake system. Journal of Aquatic Animal Health 18:157-175.

Morand, S., K. Rohde, and C. Hayward. 2002. Order in ectoparasite communities of marine fish is explained by epidemiological processes. Parasitology 124:57-63.

Moravec, F., AND D.P. Barton. 2015. Two gonad-infecting species of Philometra (Nematoda: Philometridae) from marine fishes off the coast of Australia. Parasites 22:1-9.

Muñoz, G. 2014. Parasites communities in the clingfish Gobiesox marmoratus from central Chile. Acta Parasitologica 59:108-114.

Murcia, S., B.L. Kerans, T.M. Koel, and E. MacConnell. 2015. Myxobolus cerebralis (Hofer) infection risk in native cutthroat trout Oncorhynchus clarkii (Richardson) and its relationships to tributary environments in the Yellowstone Lake Basin. Journal of Fish Disease 38:637-652.

Nannini, M.A., And M.C. Belk. 2006. Antipredator responses of two native stream fishes to an introduced predator: does similarity in morphology predict similarity in behavioural response? Ecology of Freshwater Fish 15:453-463.

Nehring, R.B., G. Schisler, L. Chiaramonte, A. Horton, AND B. POOLE. 2015. Assessment of the long-term viability of the myxospores of Myxobolus cerebralis as determined by production of the actinospores by Tubifex tubifex. Journal of Aquatic Animal Health 27:50-56.

Pérez-del-Olmo, A., M. Fernandez, and J.A. Raga. 2009. Not everything is everywhere: the distance decay of similarity in a marine host-parasite system. Journal of Biogeography 36:200-209.

Poulin, R., AND M.R. Forbes. 2012. Meta-analysis and research on host-parasite interactions: past and future. Evolutionary Ecology 26:1169-1185.

Pritchard, M.H., and G.O.W. Kruse. 1982. The collection and preservation of animal parasites. Technical Bulletin No 1. University of Nebraska Press, Lincoln, NE. 141 pp.

Rossiter, W., AND M.V.K. SukHDEO. 2014. Habitat-based constraints on food web structure and parasite life cycles. Oecologia 174:1311-1321.

Sigler, W.F., AND J.W. Sigler. 1987. Fishes of the Great Basin: a natural history. University of Nevada Press, Reno, NV.

Strona, G. 2015. The underrated importance of predation in transmission ecology of direct lifecycle parasites. Oikos 124:685-690.

Timi, J.T., AND R. Poulin. 2003. Parasite community structure within and across host populations of a marine pelagic fish: how repeatable is it? International Journal for Parasitology 33:1353-1362.

Timi, J.T., M.A. Rossin, A.J. Alarcos, P.E. Braicovich, D.M.P. Cantatore, and A.L. Lanfranchi. 2011. Fish trophic level and similarity of non-specific larval parasite assemblages. International Journal for Parasitology 41:309-316.

VinCENT, A.G., AND W.F. FONT. 2003. Host specificity and population structure of two exotic helminths, Camallanus cotti (Nematoda) and Bothriocephalus acheilognathi (Cestoda), parasitizing exotic fishes in Waianu stream, O'ahu, Hawaii. Journal of Parasitology 89: 540-544.

Weichman, M.A., And J. JanOvy. 2000. Parasite community structure in Pimephales promelas (Pisces: Cyprinidae) from two converging streams. Journal of Parasitology 86:654-656.

Wesner, J.S., AND M.C. BelK. 2015. Variation in the trophic position of common stream fishes and its relationship to the presence of a rare fish, northern leatherside chub (Lepidomeda copei). Ecology of Freshwater Fish 24:234-241.

Received 23 March 2016 Accepted 26 April 2016 